\section{EPISTEMOLOGI PENDIDIKAN KARAKTER ISLAMI DI MADRASAH IBTIDAIYAH}

\author{
Ari Purnomoaji, Abdul Wachid B.S.
}

Page | 19

Program Studi Magister Pendidikan Guru Madrasah Ibtidaiyah, IAIN Purwokerto 201763001@mhsiainpurwokerto.ac.id, abdulwachidbs@iainpurwokerto.ac.id

\begin{abstract}
Abstrak
Epistemologi ialah cabang ilmu filsafat yang mengkaji tentang ilmu pengetahuan yang melingkupi beberapa bagian ruang lingkup atau cakupan yang meliputi beberapa sumber, karakter serta hakikat manusia. Pendidikan karakter pada sekolah atau satuan pendidikan cenderung pada pembentukan atau penciptaan budaya sekolah atau dalam hal ini madrasah yaitu nilai-nilai yang mendasari integritas, adat atau tradisi, kebiasaan keseharian, serta simbol-simbol yang diterapkan oleh seluruh warga sekolah atau madrasah, dan masyarakat sekitarnya tanpa terkecuali. Tujuan penelitian ini adalah untuk mengetahui bagaimana epistemologi pendidikan karakter islami di Madrasah Ibtidaiyah. Penelitian ini menggunakan metode penelitian kualitatif deskriptif. Data yang digunakan adalah data kualitatif. Data diperoleh dari observasi, wawancara, dan dokumentasi. Teknik analisis data yang digunakan dalam penelitian ini adalah analisis kualitatif dan hermeneutika (interpretasi). Pendidikan karakter islami diterapkan melalui kegiatan pembiasaan yang dilakukan di madrasah. Guru memiliki kedudukan sangat penting dalam membentuk karakter siswa yang islami. Guru akan menjadi contoh atau tauladan bagi para peserta didiknya. Diantara kegiatan pembiasaan di madrasah yang membentuk karakter islami diantaranya adalah program pembiasaan yang selalu berjalan setiap hari mulai dari berangkat sekolah, saat mengawali pembelajaran, di dalam pembelajaran itu sendiri, akhir pembelajaran, dan juga pada program tahunan yang sudah berjalan. Untuk program pembiasaan diantaranya adalah bersalaman dengan guru saat berada di gerbang sekolah, sholat dhuha berjamaah, shalat dhuhur berjamaah, tadarus Al Qur'an, dan Tahfidz Juz Amma, boarding class bagi kelas VI, kegiatan tahsin, dan juga infaq jum'at. Pembiasaan dan program ini akan membentuk karakter islami yang hormat dengan guru, dekat dengan Allah SWT, rajin sholat, cinta al qur'an, taqwa, peduli sesama, dan soleh solehah.
\end{abstract}

Kata kunci : epistemologi, pendidikan, karakter islami,

\begin{abstract}
Epistemology is a branch of philosophy that studies science which covers several parts scope or scope which includes several sources, character and human nature. Character education in schools or educational units tends to form or create school culture or in this case madrasas, the values that underlie integrity, customs or traditions, daily habits, and symbols that are applied by all members of school or madrasa, and their surrounding community. Without exception. The purpose of this study was to find out how the epistemology of Islamic character education in Madrasah Ibtidaiyah. This study uses descriptive qualitative research methods. The data used is qualitative data. Data obtained from observations, interviews, and documentation. The data analysis techniques used in this research are qualitative analysis and hermeneutics (interpretation). Islamic character education is applied through habituation activities carried out in madrasas. Teachers have a very important position in shaping Islamic character of students. The teacher will be an example or role model for the students. Among the habituation activities in madrasas that shape Islamic character are habituation programs that always run every day starting from going to school, when starting learning, in learning itself, at the end of learning, and also in annual programs that are already running. The habituation programs include shaking hands with the teacher at the school gate, praying dhuha, praying dhuhur, tadarus Al
\end{abstract}


Qur'an, and Tahfidz Juz Amma, boarding classes for 6th graders, tahsin activities, and also Friday infaq. This habituation and program will shape an Islamic character who respects teachers, is close to Allah SWT, prays diligently, loves the Qur'an, taqwa, cares for others, and is pious.

Keywords: epistemology, education, Islamic character

Page | 20

\section{A. Pendahuluan}

Pendidikan budi pekerti atau karakter merupakan tujuan utama dalam aspek pendidikan Indonesia di era sekarang. Pendidikan budi pekerti menjadi jawaban atas permasalahan degenerasi akhlak peserta didik yang melanda negara Indonesia sehingga melahirkan dampak negatif di berbagai sisi kehidupan. Dampaknya, manusia yang memiliki adab semakin sedikit dan hampir tidak nampak dalam kehidupan sehari-hari atau berbangsa serta bernegara.

Karakter menurut KBBI adalah sifat-sifat psikologis, akhlak dan budi pekerti yang memisahkan seseorang dari yang lain. ${ }^{1}$ Character according to language means habit, whereas according to terms, character is a system of beliefs and habits that direct the actions of an individual. ${ }^{2}$ Karakter acap kali diasosiasikan dengan sebutan yang disebut dengan kepribadian yang makin membuat pemusatan pada arti psikososial yang dikaitkan melalui pendidikan serta kondisi lingkungan. Karakter dipandang dari segi behaviorial lebih mementingkan atas faktor somatopsikis yang dipunyai manusia semenjak lahir. Dapat kita simpulkan bahwa karakter ialah nilai-nilai yang spesifik baik tertanam dalam diri serta terejawantahkan dalam kelakuan. Karakter secara konsisten memancar dari hasil pikiran, ulah hati, daya rasa dan kehendak, serta gerak badan seseorang maupun sekelompok manusia.

Terminology pembelajaran karakter mulai gempar menjadi pembicaraan mulai tahun 1990. Seorang tokoh yang bernama Thomas Lickona disebut sebagai pembawanya dengan karyanya dengan bertajuk, The Return of Character Education. Sebuah karya yang membangkitkan masyarakat Barat bahwa pembelajaran karakter ialah sebuah kewajiban. Jika dilihat kata character berakar dari bahasa Yunani charassein, yang bermakna to engrave (menggambar atau melukis), bagaikan orang yang menggambar di kertas,

\footnotetext{
${ }^{1}$ Departemen Pendidikan Nasional, Kamus Besar Bahasa Indonesia, Jakarta: Pusat Bahasa, 2008, hlm. 639.

${ }^{2}$ Fitria Martanti, Integration Of Aswaja Teaching: Concept Of Strengthening Character Education in College<https://www.publikasiilmiah.unwahas.ac.id/index.php/TWS/article/view/3436\%0D>.
} 
mengukir di batu. Berasal dari penafsiran yang semacam itu, character lalu dimaknai sebagai simbol atau identitas khusus, serta sebabnya mencetuskan atau mendatangkan suatu pemikiran atau pandangan yakni karakter merupakan pola kepribadian dan perilaku yang berwatak individual, kondisi moral seseorang. ${ }^{3}$

Menurut Mahfud, Epistemologi berakar dari bahasa Yunani dari sebuah kata "epistem" dengan memiliki arti pengetahuan atau sebuah ilmu pengetahuan. "Logos" memiliki arti yaitu pengetahuan. ${ }^{4}$ Jadi epistemologi ialah cabang ilmu filsafat yang mengkaji tentang ilmu pengetahuan yang melingkupi beberapa bagian ruang lingkup atau cakupan yang meliputi beberapa sumber, karakter serta hakikat manusia. Dalam epistemologi sering menjadi pembicaraan yaitu berhubungan dengan sumber pengetahuan serta susunan atau sistematikanya, selain itu juga epistemologi ada untuk memperbincangkan mengenai hakikat akurasi atau kecermatan struktur berpikir yang secara kritis juga dipakai dalam permasalahan-permasalahan yang mempunyai sebuah hubungan dengan implikasi untuk menemukan dan menciptakan validitas isi sebuah permasalahan dan pertanyaan.

Materi pokok epistemologi ialah segala proses yang berperan serta dalam upaya kita untuk mendapatkan dan memperoleh sebuah pengetahuan. Teknik untuk mendapatkan sebuah pengetahuan ini yang menjadikan objek filosofi pengetahuan serta sekalian berguna mengantarkan terwujudnya tujuan dari sebuah epistemologi. Epistemologi tidak hanya untuk mendapatkan pengetahuan secara cuma-cuma semata, melainkan hanya untuk menciptakan kapasitas yang terdapat dalam internal pribadi manusia guna mendapatkan pengetahuan serta kaidah-kaidah dan urutan-urutan yang membolehkan manusia selama bisa memahami dan mengetahui. ${ }^{5}$

Selain pendapat tersebut di atas para ahli pembelajaran yang lainnya yaitu Hamlyn Epistemologi atau teori pengetahuan ialah cabang ilmu filsafat yang berurusan

\footnotetext{
${ }^{3}$ Ajat Sudrajat, Mengapa Pendidikan Karakter, 2011, hlm. 2.

${ }^{4}$ Mirza Mahbub Wijaya Junaedi Mahmud, Pengembangan Paradigma Keilmuan Perspektif Epistemologi Islam, 2019.

${ }^{5}$ Muljamil Qomar, Epistemologi pendidikan Islam: dari metode rasional hingga metode kritik, Jakarta; Erlangga,diakses7Mei2021,https://books.google.co.id/books?id=dXwnu_Y_n2EC\&pg=PA124\&dq=epistemolog i+pendidikan+karakter\&hl=ban\&sa=X\&ved=2ahUKEwi8uJ6t17bwAhXLX30KHRf3C6MQ6AEwAHoECAIQ $\mathrm{Ag} \# \mathrm{v}=$ onepage $\& \mathrm{q} \& \mathrm{f}=$ false.
} 
dengan hakikat dan lingkup pengetahuan, pengandaian-pengandaian, dan dasar-dasarnya serta pertanggungjawaban atas pernyataan mengenai pengetahuan yang dimiliki. ${ }^{6}$

Dalam penelitian yang dilakukan oleh Wan Mohd Fazrul Azdi Wan Razali diambil kesimpulan bahwa epistemologi adalah sebuah ilmu yang mengkaji dan mengulas tentang teori serta hakikat yang berhubungan dengan ilmu pengetahuan. Epistemologi berasal dari 2 kata bahasa Yunani, yaitu episteme yang artinya pengetahuan dan logos, perpaduan kedua kalimat tersebut ternyata membentuk satu bidang ilmu serta melahirkan cabang pokok dalam sebuah ilmu ideologi atau falsafah, yaitu analisis ilmu. Pengkajian dalam sebuah epistemologi cara mudahnya diantaranya yaitu, bagaimanakah bentuk ilmu, apakah sumber ilmu pengetahuan, di manakah kedudukannya ilmu, serta bagaimana seseorang yang memiliki ilmu itu memahami ilmu. ${ }^{7}$

Hasil penelitian Koko Adya Winata dkk dapat diambil kesimpulan bahwa Landasan ontologi dalam pendidikan karakter semakin memfokuskan kepada perspektif hakikat keberadaan, yang dipahami keberadaan di sini ialah keberadaan atau eksistensi pendidikan karakter. Epistemologi pendidikan karakter merupakan pencarian metode dan model pendidikan karakter yang tepat untuk diterapkan kepada peserta didik. ${ }^{8}$

Selain itu dalam penelitian lain yang dilakukan oleh Asep Kurniawan bisa diambil kesimpulan yaitu epistemology islam adalah daya gerak untuk perkembangan sumber daya manusia. ${ }^{9}$

Berangkat dari pemaparan penelitian ini, maka perlu dilaksanakanan penelitian tentang pendidikan berkarakter islami peserta didik Madrasah Ibtidaiyah di MI YAPPI Planjan Kecamatan Kesugihan Cilacap. Berdasarkan uraian tersebut rumusan masalah khusus penelitian ini yaitu: Bagaimanakah pendidikan karakter yang islami pesertda didik di MI YAPPI Planjan Kecamatan Kesugihan Cilacap kajian epistemologi.

Dalam penelitian ini memakai sebuah metode yaitu kualitatif deskriptif. Menurut Sugiono, pengkajian atau penelitian kualitatif merupakan sebuah penelitian dimana seorang peneliti akan ditempatkan menjadi perangkat utama atau kunci, dengan teknik

\footnotetext{
${ }^{6}$ Amsal Bakhtiar, Filsafat Ilmu, 1 ed., Jakarta: RajaGrafindo Persada, 2014.

${ }^{7}$ Wan Mohd Fazrul Azdi Wan Razali, Epistemologi Islam Vis-À-Vis Teori Demarkasi Ilmu : Satu Penelitian Awal, 'Ulūm Islāmiyyah Journal 9, no. December2012(2012):5975,https://doi.org/10.12816/0002841.

${ }^{8}$ Koko Adya Winata, Sahudi, dan Aan Hasanah, Landasan Teori Pendidikan Karakter Disekolah (Tinjauan Ontologi, Epistimologi Dan Aksiologi, Jurnal Al Amar 1, no. 3, 2020, hlm. 50-56.

${ }^{9}$ Asep Kurniawan, Pengembangan Sumber Daya Manusia Dalam Perspektif Epistemologi Filsafat Islam, Ulumna Jurnal Studi Keislaman 17, 2013, hlm. 213-30.
} 
pengumpulan datanya dilaksanakan dengan cara menggabungkan serta menganalisis data yang sifatnya induktif. ${ }^{10}$ Sedangkan menurut Poerwandari bahwa penelitian kualitatif akan mengolah serta menghasilkan data bersifat deskriptif, contohnya transkripsi dokumen observasi serta wawancara. ${ }^{11}$ Kirk dan Miller (dalam Moloeng) mengartikan bahwa penelitian kualitatif sebagai bentuk cara melakukan sebuah pengamatan secara langsung kepada individu serta bersinggungan langsung melalui orang-orang yang ada dalam penelitian itu untuk menghasilkan data yang dicarinya. ${ }^{12}$

Dengan demikian menurut pokok rumusan masalah yang akan dijadikan fokus utama pada penelitian ini adalah representasi deskriptif terkait pendidikan karakter peserta didik di MI YAPPI Planjan Kecamatan Kesugihan, maka dari itu peneliti memakai pendekatan kualitatif yaitu melalui cara mendeskripsikan sebuah data yang didapat oleh peneliti sebagai bahan hasil pengkajian atau penelitian. Sehingga dengan memakai pendekatan metode tersebut, lalu peneliti akan memperoleh sebuah data lebih menyeluruh serta bisa dideskripsikan secara jelas dan rinci maka produk penelitiannya benar-benar sinkron dengan suasana lapangan yang diteliti.

\section{B. Metode Penelitian}

Metode penelitian ini merupakan merode penelitian diskriptif kualitatif. Penelitian deskriptif memiliki tujuan untuk memberikan gambaran atau deskripsi tentang suatu keadaan secara objektif . ${ }^{13}$ Metode pengumpulan data dilaksanakan dengan cara wawancara, pengamatan atau observasi, serta dokumentasi. Teknik wawancara adalah pertemuan antara dua orang untuk menggali informasi serta ide atau gagasan dengan tanya jawab, sehingga bisa dicarikan arti dalam suatu tema tertentu. ${ }^{14}$ Wawancara ini dilakukan kepada Rafiq Primanto, Iqbal al Basith, Adi Pancoro, Alfi Hifayati, Apriana Faujiyah, Ulfah Sabani, Indri Hikmawati, Annisa Rahmawati dan Asih sutiana.

Selain wawancara data dikumpulkan dengan observasi atau pengamatan yang ditujukan kepada suatu kegiatan yang memperhatikan secara cermat dengan

\footnotetext{
${ }^{10}$ Sugiyono, Metode Penelitian Kuantitatif,Kualitatif dan R\&D, 22 ed., Bandung: Alfabeta, 2015.

${ }^{11}$ E.K. Poerwandari, Pendekatan Kualitatif untuk Penelitian Perilaku Manusia, Jakarta: LPSP3, 2007.

${ }^{12}$ Lexy J. Moleong, Metodologi Penelitian Kualitatif, 36 ed, Bandung: PT Remaja Rosdakarya, 2017.

${ }^{13}$ FitriaMartanti, Peran Guru Kelas Dalam Memberikan Layanan Bimbingan dan Konseling di SDN Watuaji01KabupatenJepara,Magistra,6(2015)<https://publikasiilmiah.unwahas.ac.id/index.php/MAGISTRA/arti cle/view/1776\%0D>. hlm 27

${ }^{14}$ Sugiyono, Metode Penelitian Kualitatif, ed. oleh Sofia Yustiani Suryandari, 3 ed, Bandung: Alfabeta, 2020.
} 
mempertimbangkan interaksi antar unsur dalam fenomena sebuah pengamatan dengan menghasilkan data mengenai sebuah permasalahan, jadi akan diperoleh suatu pemahaman atau digunakan untuk instrumen re-checking maupun informasi atau konfirmasi terhadap penjelasan informasi dan keterangan yang didapatkan sebelumnya. ${ }^{15}$ Adapun pengamatan atau observasi dilakukan pada kegiatan supervisi pendidikan dan pembiasaan di madrasah. Untuk mendukung data pengamatan atau observasi dan wawancara, dalam penelitian tersebut juga meneliti dokumen. Pengertian dokumentasi adalah menggali data tentang variabel atau keadaan yang berupa tulisan, buku, transkip, website, surat kabar, prasasti, majalah, notulen, dan agenda yang berhubungan dengan tema pembahasan yang akan diteliti. ${ }^{16}$ Jadi dalam penelitian tersebut dokumen yang akan diteliti adalah dokumen supervisi, pembiasaan dan program.

Teknik Analisis data merupakan proses mengkaji dan menyusun secara terstruktur dan sistematis data hasil pengamatan atau observasi, wawancara, dan dokumentasi melalui cara mengorganisasikan data serta memilah mana yang menjadi pokok penting dan mana yang mesti dipelajari serta melakukan kesimpulan sehingga akan mudah dipahami. ${ }^{17}$

\section{Hasil dan Pembahasan}

Lickona menyatakan bahwa pendidikan karakter adalah suatu usaha yang disengaja untuk membantu seseorang sehingga bisa memahami, memperhatikan, dan melakukan nilai-nilai etika yang pokok. Pendidikan karakter cenderung disetarakan dengan karakter atau kepribadian. Seseorang yang mempunyai karakter berarti mempunyai kepribadian atau karakter. Kedua-duanya didefinisikan sebagai totalitas atau keutuhan nilai yang dipunyai seseorang dengan menghadapkan manusia dalam menempuh kehidupannya. Keseluruhan nilai meliputi akhlak, tabiat, karakter, budi pekerti dan kepribadian kejiawaan yang lain. ${ }^{18}$ Pendidikan karakter adalah suatu cara pembentukan nilai-nilai karakter pada warga sekolah khususnya peserta didik yang mencakup unsur pengetahuan, kesadaran serta tindakan untuk melakukan nilai-nilai karakter itu. Pendidikan karakter bertumpu dari karakter dasar manusia yang sumbernya berasal dari nilai moral keseluruhan dan bersumber dari agama yang kita sebut sebagai the golden rule.

\footnotetext{
${ }^{15}$ Deddy Mulyana, Metode Penelitian Kualitatif, Bandung: Remaja Rosdakarya, 2006.

${ }^{16}$ Arikunto Suharsimi, Prosedur penelitian suatu pendekatan praktik, Jakarta: Rineka Cipta, 2006.

${ }^{17}$ Sugiyono, Metode penelitian kuatintatif, kualitatif dan R \& D, Bandung: Alfabeta, 2018.

${ }^{18}$ Abdul Majid dan Dian Andayani, Pendidikan Karakter Perspektif Islam, PT Remaja Rosdakarya, 2017.
} 
Menguraikan dan menumbuhkan teori bermakna merivisi teori yang telah ada, menafsirkan teori yang terdahulu atau menciptakan teori terbaru. Meninjau dan memperbaiki teori yang telah ada dalam sebuah pendidikan karakter memiliki arti melengkapi teori yang sudah ada supaya sesuai dengan kebutuhan. Sedangkan menciptakan teori baru berarti merancang teori yang sama sekali belum ada atau baru yang menjelaskan tentang pendidikan karakter. Epistemologi pendidikan karakter merupakan pencarian metode dan model pendidikan karakter yang tepat untuk diterapkan kepada peserta didik. Landasan epistemologi pendidikan karakter merupakan fenomenologi dengan segala persyaratan dan perangkatnya yang disebut sebagai komponen ilmu pendidikan karakter. Menurut Lickona, pendidikan karakter direncanakan mempunyai tiga aspek yang sama-sama saling terkait yaitu moral feeling, moral action, and moral knowing. Sehingga dapat dapat disimpulkan bahwa karakter yang baik mempunyai tiga kompetensi, yakni ada keinginan terhadap hal yang baik (desiring the good), melakukan hal yang baik (Doing the good), dan mengetahui hal yang baik (knowing to good) sehingga pada kesempatannya ia menjadi kelaziman hati, kelaziman bertindak dan kelaziman berfikir. ${ }^{19}$

Pendidikan karakter di sekolah atau satuan pendidikan cenderung pada penanaman atau penciptaan budaya sekolah atau dalam hal ini madrasah yaitu nilai-nilai yang mendasari integritas, adat atau tradisi, kebiasaan keseharian, serta simbol-simbol yang diterapkan oleh seluruh warga sekolah atau madrasah, dan masyarakat sekitarnya tanpa terkecuali. Di dalam setting madrasah atau sekolah, tujuan pendidikan karakter antara lain adalah mengukuhkan dan menguraikan nilai-nilai kehidupan yang dirasa penting atau pokok dan sangat perlu sehingga tercapai kepribadian atau kepemilikan peserta didik yang spesifik sebagaimana nilai-nilai yang diuraikan; 2) merevisi tingkah laku peserta didik yang tidak sesuai dengan nilai-nilai yang diterapkan oleh sekolah atau madrasah; 3) mewujudkan koneksi yang kepaduan dengan anggota keluarga dan warga masyarakat dalam menjabat tanggung jawab pendidikan karakter dengan cara bersamasama. $^{20}$

\footnotetext{
${ }^{19}$ Aisyah Aisyah, Emosda, dan Suratno, Implementasi Pendidikan Karakter Di SDIT Nurul Ilmi Kota Jambi, Tekno Pedagogi 5, no. 1, 2015.

${ }^{20}$ Raihan Putry, Nilai Pendidikan Karakter Anak Di Sekolah Perspektif Kemendiknas, GenderEquality: International Journal of Child and Gender Studies4,no.1,2019,hlm.39,https://doi.org/10.22373/equality.v4i1.4480.
} 
Seorang pendidik atau guru memiliki kedudukan yang sangat vital dalam membentuk pribadi dan karakter peserta didik. Kedudukan guru sebagai subyek di dalam proses berlangsungnya pendidikan mempunyai tanggung jawab yang besar dalam mengelaborasi kemampuan peserta didiknya supaya menjadi manusia yang berakal budi. Guru harus memiliki kompetensi yang dapat menstimulus peserta didik untuk dapat hidup dengan alam yang lebih luas sebagai realitas dari kehidupan. Keberadaan kehidupan akan berlangsung dengan baik manakala manusia memiliki akal budi dan senantiasa bertanggung jawab atas martabatnya. Sehingga oleh sebab itu, semua guru atau pendidik wajib menjadikan dirinya sebagai potret keteladanan yang berwibawa atau berkarisma bagi para peserta didiknya. ${ }^{21}$

Tindakan dan tingkah laku seseorang guru atau pendidik sangat melekat dalam diri pribadi peserta didik, maka segala kelakuan, ucapan, serta kepribadian seorang guru atau pendidik menjadi gambaran peserta didiknya. Kegiatan belajar mengajar tidak hanya menyupai ilmu pengetahuan, keterampilan, dan teknologi, tetapi juga menyuplai kehidupan. Keterlibatan yang sangat dekat ialah semua pengajar atau guru, tidak pandang pelajaran yang diajarkannya mempunyai sebuah tanggung jawab membentuk karakter serta moral peserta didik. ${ }^{22}$

\section{Epistemologi Pendidikan Karakter Islami}

Dalam epistemologi islam mempunyai dasar teologis atau ilmu agama berupa konteks pijakan mutlak. Pada epistemologi islam menegaskan totalitas atau keutuhan pengalamaan dan hakikat serta merekomendasikan banyak model untuk mengeksplorasi alam, maka ilmu dapat diterima dari wahyu serta akal, dari pengamatan atau observasi dan intuisi, berasal dari tradisi serta pemikiran teoritis. Maka dari itu epistemologi islam menegaskan investigasi semua konstruksi ilmu pengetahuan dalam bentuk nilai-nilai abadi yang menggambarkan landasan pokok atau utama peradaban islam. Selain itu epistemologi islam disebut juga sebagai alat yang mudah dalam mendapatkan banyak ilmu pengetahuan, baik itu pengetahuan yang berlandaskan data atau dokumen empirik, pengetahuan yang didapat dengan metode pendekatan

\footnotetext{
${ }^{21}$ Omeri N, Pentingnya Pendidikan Karakter Dalam Dunia Pendidikan, Nopan Omeri 9, no. manager pendidikan, 2005, hlm. 464-68.

${ }^{22}$ Leonie Francisca dan Clara Ajisuksmo, The Correlations Among Moral Knowing, Moral Feeling, and MoralBehavioronFourBasicCompetenciesofTeachers,"JurnalKependidikan45,no.2(2015):21121,https://journal.u ny.ac.id/index.php/jk/article/view/7500/6497.
} 
akademis terhadap permasalahan-permasalahan filsafat, pengetahuan dengan naluri, maupun pengetahuan yang didapat dari informasi wahyu atau petunjuk (Al Qur'an serta Hadits) atau yang dapat disebut dengan khabar shadiq.

Dalam islam pada hakikatnya tidak pernah memperselisihkan antara satu jenis pengetahuan dengan suatu pengetahuan yang lain. Demikian juga islam tidak mempertemukan satu jenis pendekatan keilmuan beserta banyak macam pengetahuan yang didapatkan. Respons islam terhadap beraneka jenis pendekatan keilmuan beserta produk-produknya sekaligus, sebab islam menatap bahwa segala pengetahuan asalnya dari Allah SWT.

Padahal menurut Al- Jabiri, bahwa epistemologi islam mempunyai tiga arahan atau tendensi, yakni bayani, irfani, serta burhani. Yang pertama epistemologi bayani merupakan epistemologi dengan memperkirakan sumber ilmu ialah naskah (nash) yang memiliki arti penalaran dari naskah. Yang kedua epistemologi irfani ialah epistemologi dengan memastikan sumber ilmu pengetahuan yaitu ilham atau petunjuk. Pada epistemologi ini mempunyai cara yang spesifik dalam memperoleh pengetahuan, yaitu yang disebut kasyf. Kita tahu bahwa cara ini termasuk sangat spesifik atau memiliki kekhasan sebab tidak bisa dilogiskan, diperdebatkan atau diverifikasi. Selain itu epistemologi ini tidak mudah dijelaskan, sebab seseorang wajib menjalaninya sendiri untuk dapat memahaminya. Penganut epistemologi ini adalah para kelompok sufi. Yang ketiga epistemologi burhani ialah epistemologi yang beranggapan bahwa asal pengetahuan ialah daya pikir. Menurut Ibn Khaldun menyebutkan bahwa epistemologi ini memakai sebuah istilah al ulum al aqliyyah.

Pada dasarnya epistemologi pendidikan karakter islami harus berdasarkan kepada dasar agama islam yaitu Al Qur'an dan As Sunah. Maka selain itu, perbuatan, tutur kata, serta tindakan para sahabat patut dijadikan sumber serta penunjuk ketika memutuskan tujuan pendidikan karakter islam. Apalagi, para sahabat bagaikan bintangbintang yang ada di langit apabila seorang kaum muslimin mengikutinya maka seseorang tersebut akan selamat terlindung dan akan mendapatkan petunjuk.

\section{Hakikat Siswa atau Peserta Didik}

Dalam filsafat pendidikan islam, guna memahami hakikat peserta didik, tidak bisa terlepas kaitannya dengan sebuah pembahasan mengenai hakikat manusia itu sendiri, sebab manusia adalah berasal dari suatu sistem pendidikan. 
Menelaah konsep pedoman islam pada hakikatnya ialah makhluk ciptaan Allah swt. yang menurut biologis diciptakan dengan proses perkembangan serta pertumbuhan dengan berproses menurut evolusi atau perkembangan, yakni dengan cara mengalami suatu proses yang berjenjang atau bertahap. Manusia sebagai insan ciptaan, mempunyai bentuk atau struktur yang lebih sempurna, lebih baik, dan lebih indah jika dibandingkan dengan makhluk lain yang ciptaan Allah swt., sehingga manusia dinilai sebagai insan atau makhluk yang lebih mulia, pada sisi lain manusia adalah makhluk yang cakap dan mampu dalam mendidik, serta bisa dididik, sebab manusia dianugerahi beberapa potensi dan kemampuan yang bisa dikembangkan. Maka itulah diantaranya refleksi tentang pemikiran islam terkait hakikat manusia, yang dijadikan refrensi pemikiran terkait hakikat peserta didik dalam dimensi pendidikan islam. Manusia yang disebut dengan peserta didik yang ada di pendidikan Islam wajib mendapatkan suatu perlakuan yang searti, selaras dan seimbang dengan hakikat yang melekat sebagai makhluk ciptaan Allah swt. Oleh karena itu, sistem pendidikan islam pada peserta didik tidak sekedar sebatas pada suatu objek pendidikan, tetapi juga sekaligus sebagai subjek pendidikan.

Sementara pendidikan islami dalam perspektif falsafah, bahwa seluruh makhluk pada hakikatnya merupakan peserta didik. Karena, dalam islam, sebagai muaddib, mu'allim, dan murabbi Allah swt pada hakikatnya ialah pendidik untuk semua makhluk ciptaan-Nya. Allah swt. yang menciptakan serta memelihara semua makhluk di muka bumi. Dalam pemeliharaan Allah swt meliputi sekaligus kependidikan-Nya, baik dalam arti ta'lim, ta'adib ataupun tarbiyah. Sebab, pendidikan islam dalam perspektif falsafah, peserta didik tersebut mencakup semua makhluk Allah swt, seperti manusia, malaikat, jin, hewan, tumbuhan, dan yang lainnya. ${ }^{23}$

\section{Peran Seorang Guru atau Pendidik dalam Pendidikan Karakter Islami}

Pendidik atau guru adalah garda terdepan dari pendidikan di madrasah, karena merekalah yang berhadapangan secara langsung dengan peserta didik. Peran seorang guru sangat penting guna menunjang tercapainya tujuan pendidikan. Ketika memasukkan pendidikan karakter islami, semua pendidik atau guru wajib menjadi

\footnotetext{
${ }^{23}$ AlRasyidin,FalsafahPendidikanIslami,CitapustakaMediaPerintis,2008,https://books.google.co.id/books? $\mathrm{hl}=\mathrm{id} \& \mathrm{lr}=\& \mathrm{id}=\mathrm{VLST} 0 \mathrm{FNBlMgC} \& \mathrm{i}=\mathrm{fnd} \& \mathrm{pg}=\mathrm{PA} 3 \& \mathrm{dq}=\mathrm{al}+$ rasyidin\&ots=zsiu9RNyJ\&sig=jwbSw4oGygxIL2 uyJx8Z6N4E\&redir_esc=y\#v=onepage\&q\&f=false.
} 
sumber kreativitas dalam berkarakter bagi siswa atau peserta didiknya. Guru tidak hanya menjadi pengajar di madrasah tetapi juga menjadi pendidik moral dan karakter peserta didik.

Berdasarkan hasil observasi di MI YAPPI Planjan dan wawancara dengan bapak dan ibu guru bahwa secara maksimal guru sudah memberikan contoh atau tauladan bagi para peserta didiknya. Hal ini terlihat pada kegiatan pembiasaan yang dapat membentuk karakter peserta didik yang islami. Diantara kegiatan pembiasaannya adalah sebagai berikut, yang pertama adalah para guru menyambut datangnya peserta didik dengan berbaris di gerbang sekolah sambil mengucap salam serta berjabat tangan. Kegiatan ini dilakukan setiap pagi dengan model berjadwal untuk guru. Pembiasaan ini akan menumbuhkan karakter islami yaitu sebagai rasa hormat kepada guru.

Kedua adalah pembiasaan sholat dhuha berjamaah. Pembiasaan ini menurut hasil observasi dan wawancara dengan guru bahwa pelaksanaannya setalah bel dibunyikan. Jadi, peserta didik dan guru melaksanakan sholat dhuha secara berjamaah di masjid. Kegiatan ini ialah kegiatan yang sangat religius karena dapat membentuk karakter islami siswa yang akan lebih mendekatkan diri kepada Allah SWT. Peserta didik akan rajin menjalankan sholat sunah ini setiap hari.

Ketiga adalah kegiatan tadarus, menurut hasil wawancara dengan guru bahwa kegiatan tadarus dilaksanakan setiap hari jum'at. Jadi, para peserta didik dan guru akan bertadarus sebelum pelajaran dimulai. Karakter islami yang dapat diambil dari pembiasaan ini adalah peserta didik akan lebih dekat dengan Allah SWT dan akan lebih pintar dalam mengaji.

Keempat adalah Tahfidz Juz Amma, pembiasaan ini dilaksanakan setiap hari. Jadi, sebelum pelaksanaan pembelajaran peserta didik akan menghafalkan juz 30 dengan cara setor kepada gurunya. Pembiasaan ini akan membawa peserta didik memiliki karakter islami yaitu akan lebih cinta Al Qur'an.

Kelima adalah program boarding class, program ini diperuntukan bagi siswa kelas akhir yaitu kelas VI. Adanya program ini adalah bagian dari visi misi madrasah yang ingin memiliki out put bukan hanya sekedar akademik tetapi juga lulusan dari madrasah harus memiliki sikap yang religius dan bertaqwa terhadap Tuhan Yang Maha Esa. Boarding class menjadikan siswa akan lebih intensif belajar baik agama maupun umum, karena dalam program ini lebih menekankan pada kegiatan mengaji atau 
religius. Siswa akan dibawa dalam kegiatan mengaji setelah kegiatan shalat fardu secara berjamaah.

Keenam adalah tahsin, program ini masuk dalam kurikulum madrasah sehingga ada guru tersendiri yang mengampu program tahsin. Semua kelas ada program tahsin, sehingga nantinya siswa yang lulus sudah dapat membaca Al Qur'an denga benar tajwidnya dan memahami hukum bacaan yang ada dalam bacaan Al Qur'an.

Ketujuh adalah infaq jum'at, kegiatan ini dilaksanakan seluruh siswa dan guru. Jadi, siswa menyisihkan uang sakunya untuk diinfaqkan yang akan dikoordinir oleh wali kelas masing-masing. Selain siswa, guru juga diwajibkan untuk ikut berinfaq. Hal ini akan membentuk karakter siswa yang islami yaitu peduli dengan sesama karena nantinya uang yang terkumpul dalam infaq tersebut akan digunakan untuk menjenguk siswa yang sakit, kegiatan kemanusiaan, dan santunan untuk anak yatim.

Penerapan pembiasaan-pembiasaan ini harus dilaksanakan sesuai dengan kurikulum yang dibuat madrasah. Jadi, pendidikan karakter islami berimplikasi kepada pembentukan jiwa manusiawi yang kuat, pengembangan kapasitas peserta didik bersumber pada nilai-nilai keimanan dan ketaqwaan. Tetapi di sisi lain, pendidikan karakter islami bermanfaat untuk perbaikan lahir serta batin manusia serta usaha sterilisasi dari pengetahuan, pengalaman dan kepribadian menyimpang dari standar sifat akhlak terpuji. Di samping itu juga, pendidikan karakter islami dapat mejalankan adaptasi sehingga nilai-nilai yang sesuai dapat diambil mengenai nilai-nilai yang berpolemik dengan islam tidak boleh diterima dan harus ditolak.

\section{SIMPULAN}

Islam mempunyai keistimewaan yang spesifik tersendiri dalam pembentukan pendidikan karakter. Dalam pendidikan karakter islami tidak sekadar mengarah pada hal keduaniaan atau duniawi tetapi juga berorientasi pada ukhrawi. Selain hal tersebut juga, pendidikan karakter islami tidak melulu terkait hubungan antar manusia, tetapi juga hubungan kepada Allah ta'ala dan juga hubungan kepada semua makhluk, tidak tersekat manusia saja. Semua ini dikarenakan sumber pada pendidikan karakter islami tidak hanya rasio atau akal, juga tidak hanya panca indera.

Pendidikan karakter islami diterapkan dengan kegiatan pembiasaan yang dilakukan di madrasah atau sekolah. Guru mempunyai peran sangat penting dalam 
mencetak karakter siswa yang islami. Guru akan menjadi contoh atau tauladan bagi para peserta didiknya. Diantara kegiatan pembiasaan di madrasah yang membentuk karakter islami diantaranya adalah bersalaman dengan guru, sholat dhuha berjamaah, tadarus $\mathrm{Al}$ Qur'an, Tahfidz Juz Amma, boarding class bagi kelas VI, kegiatan tahsin, dan juga infaq jum'at. Pembiasaan dan program ini akan membentuk karakter islami yang hormat dengan guru, dekat dengan Allah SWT, rajin sholat, cinta al qur'an, taqwa, peduli sesama, dan soleh solehah.

\section{DAFTAR PUSTAKA}

Aisyah, Aisyah, Emosda, dan Suratno. Implementasi Pendidikan Karakter Di SDIT Nurul Ilmi Kota Jambi. Tekno Pedagogi 5, no. 1, 2015.

Bakhtiar, Amsal. Filsafat Ilmu. 1 ed. Jakarta: RajaGrafindo Persada, 2014.

Francisca, Leonie, dan Clara Ajisuksmo. The Correlations Among Moral Knowing, Moral Feeling, and Moral Behavior on Four Basic Competencies of Teachers. Jurnal Kependidikan45,no.2,2015https://journal.uny.ac.id/index.php/jk/article/view/7500/6497.

Junaedi Mahmud, Mirza Mahbub Wijaya. Pengembangan Paradigma Keilmuan Perspektif Epistemologi Islam, 2019.

Kurniawan, Asep. Pengembangan Sumber Daya Manusia Dalam Perspektif Epistemologi Filsafat Islam. Ulumna Jurnal Studi Keislaman 17, 2013

Majid, Abdul, dan Dian Andayani, Pendidikan Karakter Perspektif Islam. PT Remaja Rosdakarya, 2017.

Martanti, Fitria, Peran Guru Kelas Dalam Memberikan Layanan Bimbingan dan Konseling diSDNWatuaji01 KabupatenJepara,Magistra,6(2015)<https://publikasiilmiah.unwahas.a c.id/index.php/MAGISTRA/article/view/1776\%0D>

Martanti, Fitria, Intagration Of Aswaja Teaching: Concept Of Strethening Character EducationinCollege $<$ https://www.publikasiilmiah.unwahas.ac.id/index.php/TWS/article /view/3436\%0D>

Moleong, Lexy J. Metodologi Penelitian Kualitatif. 36 ed. Bandung: PT Remaja Rosdakarya, 2017.

Mulyana, Deddy. Metode Penelitian Kualitatif. Ban: Remaja Rosdakarya, 2006.

N, Omeri. Pentingnya Pendidikan Karakter Dalam Dunia Pendidikan. Nopan Omeri 9, no. manager pendidikan, 2005.

Nasional, Departemen Pendidikan. Kamus Besar Bahasa Indonesia. Jakarta: Pusat Bahasa, 2008.

Poerwandari, E.K. Pendekatan Kualitatif untuk Penelitian Perilaku Manusia. Jakarta: LPSP3, 2007.

Putry, Raihan. Nilai Pendidikan Karakter Anak Di Sekolah Perspektif Kemendiknas. Gender Equality: International Journal of Child and Gender Studies 4, no. 1, 2019, https://doi.org/10.22373/equality.v4i1.4480. 
Qomar, Muljamil. Epistemologi pendidikan Islam: dari metode rasional hingga metode $\begin{array}{llllll}\text { kritik. } & \text { Jakarta; } & \text { Erlangga. } & \text { Diakses } & 7 & \text { Mei }\end{array}$ https://books.google.co.id/books?id=dXwnu_Y_n2EC\&pg=PA124\&dq=epistemologi+ pendidikan+karakter\&hl=ban\&sa=X\&ved=2ahUKEwi8uJ6t17bwAhXLX30KHRf3C6 MQ6AEwAHoECAIQAg\#v=onepage \&q\&f=false.

Page|32 Rasyidin, Al. Falsafah Pendidikan Islami. Citapustaka Media Perintis, 2008. https://books.google.co.id/books?hl=id\&lr=\&id=VLST0FNBIMgC\&oi=fnd\&pg=PA3 $\& \mathrm{dq}=\mathrm{al}+$ rasyidin $\&$ ots $=\mathrm{zsiu} 9 \mathrm{RN}-\mathrm{yJ} \&$ sig $=\mathrm{jwbSw} 4 \mathrm{oGygxg}-$ OIL2uyJx8Z6N4E\&redir_esc=y\#v=onepage \&q\&f=false.

Razali, Wan Mohd Fazrul Azdi Wan. Epistemologi Islam Vis-À-Vis Teori Demarkasi Ilmu: Satu Penelitian Awal. 'Ulūm Islāmiyyah Journal 9, no. December 2012. https://doi.org/10.12816/0002841.

Sudrajat, Ajat, Mengapa Pendidikan Karakter, 2011

Sugiyono. Metode Penelitian Kualitatif. Diedit oleh Sofia Yustiani Suryandari. 3 ed. Bandung: Alfabeta, 2020.

- Metode Penelitian Kuantitatif,Kualitatif dan R\&D. 22 ed. Bandung: Alfabeta, 2015.

Sugiyono, D. Metode penelitian kuatintatif, kualitatif dan $R \& D$ / Sugiyono. Bandung: Alfabeta, 2018.

Suharsimi, Arikunto. Prosedur penelitian suatu pendekatan praktik, Jakarta: Rineka Cipta, 2006.

Winata, Koko Adya, Sahudi, dan Aan Hasanah, Landasan Teori Pendidikan Karakter Disekolah (Tinjauan Ontologi, Epistimologi Dan Aksiologi, Jurnal Al Amar 1, no. 3 2020. 